\title{
FUNGSI SEMANTIK KOSAKATA ALAT DAN TEKNIK PENANGKAPAN IKAN MASYARAKAT NELAYAN DI KAWASAN BOULEVARD MANADO
}

\author{
Irma Maria Lontoh \\ marialontoh04@gmail.com \\ Pascasarjana \\ Universitas Sam Ratulangi
}

\begin{abstract}
The purpose of this study is to describe the function of semantic vocabulary tools and fishing techniques in fisherman communities in the area of Boulevard Manado. This research uses qualitative descriptive method and uses lexical semantic study approach to analyze semantic function of vocabulary tool and fishing technique in fisherman communities. This research was conducted along the coastal area of Boulevard, Sario Sub-district, Manado City, North Sulawesi. Sources of data in this study were taken from those who work as fishermen, who know about the vocabulary tools and fishing techniques.

The data collection techniques are direct observation techniques and interviews. The data collection tool was the researcher as a key instrument. Based on the results of data analysis research found in fishing gear and techniques in Bolevard Manado area, there are 30 vocabulary in fishing gear, and 14 vocabulary in fishing technique in the form of these results collected in this study. The researcher hopes for this research continued on the vocabulary of fisherman fishing tools and techniques in the Bolevard Manado area, from different perspectives, so that further research can complement the study of semantics, especially lexical semantics with other problems.
\end{abstract}

Keywords: Function of Semantic, vocabulary tools, fishing techniques ,Fisherman communities.

\section{PENDAHULUAN}

Bahasa merupakan alat komunikasi yang tidak terlepas dari arti atau makna dari setiap perkataan yang bersifat arbiter (sewenang-wenang, berubah-ubah, tidak tetap, mana suka).Artinya tidak ada hubungan wajib antara lambang bahasa (yang berwujud bunyi) dengan konsep atau pengertian yang dimaksud oleh lambang tersebut (Chaer, 2007:45).Bahasa merupakan alat atau perwujudan budaya yang digunakan manusia untuk saling berkomunikasi. Bahasa yang terdiri atas bahasa lisan dan tulisan merupakan bagian dari keseluruhan proses dan produk manusia dan masyarakat dalam interaksinya dengan dirinya/sesamanya dan dengan alam lingkungannya. Menurut Samsuri (1983) bahasa adalah alat untuk mengkodekan kebudayaan. Sebagai suatu unsur yang dinamik, bahasa senantiasa dianalisis dan dikaji dengan berbagai pendekatan, yang antara lainnya melalui pendekatan makna, sedangkan semantik merupakan komponen bahasa yang tidak dapat dilepaskan dalam pembicaraan linguistik. Tanpa membicarakan makna, pembahasan linguistik belum dianggap lengkap karena sesungguhnya tindakan berbahasa itu tidak lain 
daripada upaya untuk menyampaikan makna-makna itu. Ujaran-ujaran yang tidak bermakna tidak ada artinya sama sekali ( Parera, 2004:17 ). Selanjutnya bahasa memiliki fungsi sebagai alat komunikasi sosial. Dalam kehidupan bermasyarakat,tentu saja manusia memerlukan alat komunikasi untuk berhubungan antar anggotanya, untuk keperluan itu digunakan suatu wahana yang disebut bahasa.Menurut Keraf (1980) bahasa adalah alat komunikasi yang khusus dilangsungkan dengan mempergunakan alat ucap manusia.

Tujuan dari proses berkomunikasi itu ialah untuk menyampaikan maksud hati atau kemauan kepada lawan bicara atau orang lain. Melalui bahasa jugalah, manusia dapat menyesuaikan diri dengan adat istiadat, tingkah laku, tata krama masyarakat, dan sekaligus mudah membaurkan dirinya dengan segala bentuk masyarakat.Sebagaimana bahasa daerah menjadi bahasa yang selalu dipakai dan menjadi bahasa keseharian bagi masyarakat sebagai perwujudan komunikasi sehari-hari di suatu tempat tertentu.Bahasa merupakan komponen komunikasi yang paling utama dalam kehidupan dan merupakan sarana untuk mengungkapkan sesuatu yang ada dalam pikiran manusia kepada sesama manusia, Melalui bahasa manusia dapat mengungkapkan seluruh aktivitas dalam kehidupannya serta berekspresi terhadap keinginan dan hasratnya. Bahasa adalah milik manusia dan merupakan alat yang ampuh untuk berinteraksi dan bekerjasama baik sebagai mahluk individu maupun sebagai mahluk sosial. Kridalaksana (1984:21) mendefinisikan bahasa sebagai lambang bunyi yang bersifat arbiter yang dipakai oleh masyarakat untuk bekerja sama, berinteraksi, dan mengidentifikasikan diri.

Kata sebagai unsur dari suatu bahasa yang diucapkan atau dituliskan merupakan perwujudan kesatuan perasaan dan pikiran yang dapat digunakan dalam berbahasa. Fakta bahwa setiap bahasa pasti mempunyai sejumlah kata.Semua itu pun terhimpun dalam suatu bentuk kosakata.Kosakata erat hubungannya dengan leksikon atau kata jika ditinjau dari ilmu leksikologi.Kosakata atau leksikon merupakan komponen bahasa yang memuat semua informasi tentang makna dan pemakaian kata dalam bahasa (Kridalaksana 2009: 142).

Spesifikasi kosakata yang dipilih dalam penelitian ini ialah kosakata alat dan teknik tangkap masyarakat nelayan. Suatu kelompok masyarakat yang hidup di wilayah pesisir tentu saja memiliki bentuk-bentuk bahasa yang lebih kaya akan kosa kata yang bermuatan makna tertentu pada masyarakat tersebut, hal ini dapat dilihat dari pola hidup mereka yang berprofesi sebagai nelayan.

Alasan memilih kosakata alat dan teknik tangkapnelayan yang menjadi pemanfaatan bagi mereka yang berprofesi sebagai nelayan.Selain itu, masyarakat nelayan 
yang masih menggunakan alat dan teknik tangkap ini pula menjadi cerminan salah satu bentuk pelestarian alat dan teknik tradisional yang dewasa ini semakin modern.Hal inilah penamaan kosakata masyarakat nelayan terutama pada alat dan teknik tangkap perlu dilestarikan dan diinventarisasikan agar kosakata ini tidak akan punah serta tetap menjadi manfaat bagi masyarakat sekitar.

Tempat penelitian atau tempat pengambilan data mengenai kosakata alat dan teknik tangkap masyarakat nelayan ini terletak di sepanj ang pesisir kawasan Boulevard, Kecamatan Sario, Kota Manado Sulawesi Utara. Alasan memilih lokasi ini sebagai tempat penelitian karena kawasan ini memiliki beberapa pondok persinggahan para nelayan atau yang disebut Dasengyang lokasinya berada di sepajang pesisir pantai pusat perkotaan Manado.Hal ini akan mempermudah dalam mengambil data mengenai kosakata mengenai alat dan teknik tangkap para nelayan yang tentu saja tidak jauh letaknya dengan tempat tinggal peneliti.

Penelitian ini menggunakan kajian semantik dan membatasinya menjadi kajian semantik leksikal khususnya pada fungsi semantik yang digunakan dalam penganalisisan data. Menurut Kridalaksana (2009: 69) fungsi semantik adalah peran unsur dalam suatu ujaran dan hubungannya secara struktural dengan unsur lain khususnya di bidang makna. Pada tataran semantik berbagai jenis makna banyak dikemukakan oleh para ahli, tidak jarang konsep jenis makna yang mereka kemukakan ada yang sama maupun berbeda. Menurut Pateda (dalam Chaer 2009: 59) menjelaskan ada 25 makna secara alfabetis.Chaer (2009: 59) menyatakan bahwa jenis-jenis makna itu adalah makna leksikal, gramatikal, kontekstual, referensial dan nonreferensial, denotatif, konotatif, konseptual, asosiatif, kata, istilah, idiom, serta makna peribahasa.Wijana (2008: 21) menyatakan bahwa jenis makna itu terdiri dari makna leksikal dan makna gramatikal, makna denotatif dan makna konotatif, makna literal dan makna figuratif serta makna primer dan sekunder. Dalam hal ini, teori yang akan diambil dalam menganalisis data yang berisi penjelasan mengenai spesifikasi makna hanya berbatas pada makna leksikal, hal ini sesuai dengan batasan masalah yang diambil.

Makna leksikal suatu kata terdapat dalam kata yang berdiri sendiri.Dikatakan berdiri sendiri sebab makna sebuah kata dapat berubah apabila kata tersebut telah berada di dalam kalimat.Dengan demikian ada kata-kata yang makna leksikalnya dapat dipahami jika kata-kata itu sudah dihubungkan dengan kata-kata yang lain (Pateda 2010: 119). Berbagai maksud dari makna leksikal telah banyak dikemukakan para ahli apabila 
mengambil simpulan dari pengertian tersebut dapat disimpulkan bahwa makna leksikal berarti makna yang sebenarnya yang ada dalam hidup, makna yang ada sesuai alat indra manusia dan makna yang mengacu pada referennya. Berhubungan dengan fungsi dan makna dalam menentukan fungsi menjadi lebih sulit sebab fungsi dan makna terjalin erat tidak dapat dipisahkan. Dalam hal ini, penelitian ini akan memaparkan fungsi dari kosakata alat dan teknik tangkap ikan berdasarkan manfaat kosakata tersebut yang diambil dari penutur bahasa Melayu Manado, Kecamatan Sario. Fungsi semantik terutama yang diacu dalam makna leksikal ini tentu sesuai dengan referennya karena unsur-unsur yang ada dalam bahasa, lepas dari penggunaannya atau konteksnya (Kridalaksana 2009: 149).

Berikut ini contoh dalam penganalisisan fungsi semantik dalam kosakata alat dan teknik penangkapan ikan sesuai dengan referen yang di informan.

Tabel 1. Contoh dalam Penganalisisan Fungsi Semantik

Kosakata Fonetik Fungsi Semantik Leksikal

Gololopo [gololopo'] berfungsi sebagi tali pancing

Nunae [nunaE] berfungsi sebagai umpan

Berdasarkan contoh table di atas, penelitian ini akan mendeskripsikan fungsi semantik khususnya semantik leksikal yang dipakai oleh penutur terhadap kosakata alat dan teknik penangkapan ikan dalam bahasa Melayu Manado. Setelah melakukan penelitian ini, paling tidak penelitian ini dapat berguna untuk referensi penelitian selanjutnya dan berguna untuk menambah pengetahuan tentang kosa kata dari masyarakat nelayan.

\section{RUMUSAN MASALAH}

Berdasarkan latar belakang pemikiran tersebut, masalah-masalah yang hendak diangkat dalam penelitian ini dirumuskan sebagai berikut :

1. Apa saja kosakata alat dan teknik penangkapan ikan yang digunakan oleh masyarakat nelayan di Kawasan Boulevard Manado ?

2. Apa fungsi kosakata - kosakata tersebut pada masyarakat nelayan di Kawasan Manado

\section{TUJUAN PENELITIAN}


1. Mengidentifikasi dan mendeskripsikan kosakata alat dan teknik penangkapan ikan yang digunakan oleh masyarakat nelayan di Kawasan Boulevard Manado.

2. Menjelaskan fungsi dari kosakata alat dan teknik penangkapan ikan yang digunakan oleh masyarakat nelayan di Kawasan Boulevard Manado.

\section{MANFAAT PENELITIAN}

Manfaat penelitian ini dibagi atas dua yakni manfaat teoretis dan praktis seperti yang diuraikan di bawah ini.

Secara teoritis:

Sebagai Penelitian Linguistik, kajian ini telah membuktikan adanya makna dan fungsi semantik pada kosakata alat dan teknik tangkap para komunitas nelayan yang ada di kawasan Boulevard Manado. Hal ini dpat memperkaya dalam kajian semantik terutama dalam menganalisis fungsi semantik leksikal pada tataran kosakata.

Secara praktis:

Hasil penelitian diharapkan dapat membuka dan memperluas pandangan bahwa ternyata dari kelompok masyarakat nelayan terdapat kajian linguistik, yang dapat diangkat dan memeperkaya wawasan serta pengertian masyarakat tentang hubungan bahasa dengan kehidupan masyarakat nelayan.Selain itu juga penelitian ini dapat menambah wawasan dalam pemahaman bahasa pada kelompok-kelompok masyarakat tersebut yang bisa menjadi cerminan dalam suatu kelompok masyarakat.

\section{TINJAUAN PUSTAKA}

Mellisa (2014) dalam artikelnya mengkaji tentang klasifikasi kosakata yang ditinjau dari bentuk dan makna, referensi kosakata tumbuhan mencakup kata atau leksikon dari berbagai-bagai tumbuhan.Spesifikasi kosakata yang dipilih dalam penelitian ini ialah kosakata etnobotani Melayu Sukadana.penelitian ini akan memaparkan fungsi dari kosakata etnobotani Melayu Sukadana berdasarkan manfaat kosakata tersebut di bidang pengobatan yang diambil dari penutur bahasa Melayu di Kecamatan Sukadana. Fungsi semantik terutama yang diacu dalam makna leksikal ini tentu sesuai dengan referennya karena unsur-unsur yang ada dalam bahasa. 
Efpriyani dkk, dalam jurnal mereka mengangkat tentang bagaimana mendeskripsikan kosakata pada Tenun Ikat Tradisional Suku Dayak Desa. Secara khusus penelitian ini bertujuan sebagai berikut: (1) Mendeskripsikan makna leksikal kosakata pada tenun ikat tradisional berupa alat, bahan, motif, dan hasil; (2) Mendeskripsikan komponen makna kosakata pada tenun ikat tradisional Suku Dayak Desa mengenai alat, motif, bahan, dan hasil; (3) Mendeskripsikan jenis makna kosakata pada tenun ikat tradisional Suku Dayak Desa mengenai alat, motif, bahan, dan hasil; (4) Mendeskripsikan peran semantis kosakata pada tenun ikat tradisional Suku Dayak Desa mengenai alat, motif, bahan, dan hasil.

Hubungan tinjauan pustaka di atas dengan penelitian ini sama-sama membahas tentang fungsi semantic kosakata, namun terdapat perbedaan antara penelitian-penelitian terdahulu dengan penelitian sekarang mengenai obyek penelitian dan sumber data yang digunakan.Penelitian ini lebih secara khusus pada obyek kosakata pada alat dan teknik tangkap ikan di kawasan Bolevard Manado.

\section{KERANGKA TEORI}

Kata semantik dalam bahasa Indonesia (Inggris: semantiks) semula berasal dari bahasa Yunani, sema (kata benda yang berarti "tanda") atau "lambang". Kata kerjanya adalah semaino yang berarti "menandai" atau "melambangkan". Yang dimaksud dengan tanda atau lambang di sini sebagai padanan kata sema itu adalah tanda linguistik(Prancis: signe linguistique) seperti yang dikemukakan oleh Ferdinand de Saussure (Chaer, 2009:2) yaitu yang terdiri dari (1) komponen yang mengartikan, yang berwujud bentuk-bentuk bunyi bahasa dan (2) komponen yang diartikan atau makna dari komponen yang pertama itu. Kedua komponen ini adalah merupakan tanda dan lambang; sedangkan yang ditandai atau dilambanginya adalah sesuatu yang berada diluar bahasa yang lazmi disebut referen atau hal yang ditunjuk.

Kata semantik ini kemudian disepakati sebagai istilah yang digunakan dalam bidang linguistik yang mempelajari hubungan antara tanda-tanda linguistik dengan hal-hal yang ditandainya. Atau dengan kata lain, bidang studi dalam linguistik yang mempelajari makna atau arti dalam bahasa. Dengan anggapan bahwa makna menjadi bagian dari bahasa, maka semantik merupakan bagian dari linguistik. Seperti halnya bunyi dan tata bahasa, komponen makna dalam hal ini juga menduduki tingkatan tertentu.Apabila komponen bunyi umumnya menduduki tingkatan pertama, tata bahasa pada tingkat kedua, 
maka komponen makna menduduki tingkatan paling akhir. Hubungan ketiga komponen itu sesuai dengan kenyataan bahwa (a) bahasa pada awalnya merupakan bunyi-bunyi abstrak yang mengacu pada adanya lambang-lambang tertentu, (b) lambang-lambang merupakan seperangkat sistem yang memiliki tataan dan hubungan tertentu, dan (c) seperangkat lambang yang memiliki bentuk dan hubungan itu mensosialisasikan adanya makna tertentu (Aminuddin, 2001:15).

Tarigan (1993:13) menyatakan bahwa semantik menelaah hubungan tanda dengan objek-objek yang merupakan wadah penerapannya.Makna, sebagai penghubung bahasa dengan dunia luar, sesuai dengan kesepakatan para pemakainya sehingga dapat saling dimengerti, dalam keseluruhannya memiliki tiga tingkatan keberadaan.Pada tingkat pertama, makna menjadi isi abstraksi dalam kegiatan bernalar secara logis sehingga membuahkan preposisi yang benar.

Tingkat kedua, makna menjadi isi dari suatu bentuk kebahasaan.Pada tingkat ketiga, makna menjadi isi komunikasi yang mempu membuahkan informasi tertentu.

Lebih lanjut, Wallace L Chafe (dalam Aminuddin, 2001:8) mengungkapkan bahwa berpikir tentang bahasa, sebanarnya sekaligus juga telah melibatkan makna.Hal ini sejalan dengan fungsi semantik itu sendiri, yaitu agar dapat mengolah pesan, menata struktur kebahasaan, serta menggunakannya dengan tepat.Seorang yang mempelajari semantik memiliki tujuan yang berbeda-beda sesuai dengan kebutuhan orang yang mempelajarinya. Bagi seorang wartawan tujuan mempelajari semantik lebih bersifat praktis sekedar untuk mengetahui makna kata yang akan mendukung berita yang akan disampaikannya kepada masyarakat pembaca (Pateda, 2010:23). Pendapat tersebut didukung oleh Chaer (2009:12) yang menyatakan bahwa seorang wartawan, seorang reporter, atau orang-orang yang bekecimpung dalam dunia persuratkabaran dan pemberitaan, mereka barangkali akan memperoleh manfaat praktis dan pengetahuan mengenai semantik. Pengetahuan semantik akan memudahkannya dalam memilih dan menggunakan kata dengan makna yang tepat dalam menyampaikan informasi kepada masyarakat umum. Tanpa pengetahuan akan konsep-konsep polisemi, homonimi, denotasi, konotasi, dan nuansa-nuansa makna tentu akan sulit bagi mereka untuk dapat menyampaikan informasi secara tepat dan benar.

Wijana (2008: 21) menyatakan bahwa jenis makna itu terdiri dari makna leksikal dan makna gramatikal, makna denotatif dan makna konotatif, makna literal dan makna figuratif serta makna primer dan sekunder. Dalam hal ini, teori yang akan diambil dalam 
menganalisis data yang berisi penjelasan mengenai spesifikasi makna hanya berbatas pada makna leksikal, hal ini sesuai dengan batasan masalah yang diambil.

Semantik leksikal dan semantik gramatikal sangat berbeda.Semantik leksikal dapat disamakan dengan semantik kata-kata. Makna kata-kata itu menunjukan adanya maknamakna secara lepas yang tidak dikaitkan dengan suatu konteks tertentu (konteks dengan kata lain). Makna leksikal (lexical meaning, semantis meaning, external meaning) adalah unsur-unsur bahasa sebagai lambang benda, peristiwa, dan lain sebagainya, atau makna yang ditimbulkan adanya hubungan antara unsur-unsur bahasa lepas dari penggunaan atau konteksnya (Kridalaksana, 1982: 103).Kamus merupakan contoh dari semantik leksikal, makna tiap-tiap kata diuraikan dalam kamus.

Makna leksikal suatu kata terdapat dalam kata yang berdiri sendiri.Dikatakan berdiri sendiri sebab makna sebuah kata dapat berubah apabila kata tersebut telah berada di dalam kalimat.Dengan demikian ada kata-kata yang makna leksikalnya dapat dipahami jika kata-kata itu sudah dihubungkan dengan kata-kata yang lain (Pateda 2010: 119).

Menurut Kridalaksana (2009: 69) fungsi semantik adalah peran unsur dalam suatu ujaran dan hubungannya secara struktural dengan unsur lain khususnya di bidang makna. Pada tataran semantik berbagai jenis makna banyak dikemukakan oleh para ahli, tidak jarang konsep jenis makna yang mereka kemukakan ada yang sama maupun berbeda.Fungsi semantik terutama yang diacu dalam makna leksikal ini tentu sesuai dengan referennya karena unsur-unsur yang ada dalam bahasa, lepas dari penggunaannya atau konteksnya (Kridalaksana 2009: 149).

\section{METODE PENELITIAN}

Penelitian ini menggunakan metode deskriptif. Metode deskriptif dipilih karena penelitian yang dilakukan semata-mata hanya melihat berdasarkan fakta yang ada di lapangan atau fenomena yang secara empiris hidup dengan penutur-penuturnya sehingga yang dihasilkan atau dicatat berupa bahasa yang dikatakan dan sifatnya seperti potret dari paparan apa adanya yang diucapkan penutur. Sudaryanto (dalam Sudartini 2010: 5) menyatakan bahwa istilah deskriptif itu menyarankan bahwa penelitian yang dilakukan semata-mata hanya berdasarkan pada fakta yang ada atau fenomena yang memang secara empiris hidup pada penutur-penuturnya.Bentuk penelitian ini ialah penelitian kualitatif.Menurut Satori (2011: 25) penelitian kualitatif adalah suatu pendekatan penelitian yang mengungkap situasi sosial tertentu dengan mendeskripsikan kenyataan secara benar, dibentuk oleh kata-kata berdasarkan teknik pengumpulan dan analisis data 
yang relevan dan diperoleh dari situasi yang alamiah.Dengan demikian, alasan pemilihan metode deskriptif kualitatif ialah karena metode ini dipandang dapat memberikan gambaran objektif mengenai penelitian ini sehingga dapat memberikan fakta sesuai subjek maupun objeknya.

Sumber data yang diperoleh dari penelitian ini adalah mereka yang bekerja sebagai nelayan di kawasan Bolevard Manado. Data dari tuturan lisan inilah yang akan direkam dan ditranskripsikan sehingga menjadi bentuk teks tertulis. Adapun syarat-syarat yang akan dijadikan penutur dalam penelitian ini sesuai dengan pernyataan Samarin (1988: 5570), yaitu penutur asli bahasa, Berusia antara 35 - 65 tahun dan tidak pikun sehingga mampu memberikan informasi berupa data yang representatif, berpendidikan serendahrendahnya setingkat SD, lahir dan dibesarkan di lokasi penelitian, menetap di lokasi penelitian dan tidak sering berpergian ke daerah luar, sehat jasmani dan rohani dan tidak cacat alat ucap. Alasan memilih penutur dengan persyaratan ini ialah karena syarat-syarat di atas dapat mewakili kriteria dalam penguasaan bahasa khususnya pada kosakata alat dan teknik tangkap ikan masyarakat nelayan. Dengan demikian, hal ini akan mempermudah penelitian dan pengambilan data di lapangan secara akurat.

Data dalam penelitian ini adalah kosakata alat dan teknik tangkap ikan yang didapatkan dari penutur asli bahasa Melayu Manado.Menurut Sudaryanto (1993: 137-139) ada beberapa teknik yang dapat digunakan dalam pengumpulan data. Teknik pengumpul data yang digunakan dalam penelitian ini, yaitu (1) teknik pancingan, teknik ini dijadikan teknik dasar penelitian, hal ini dimaksudkan agar mempermudah penutur untuk menyebutkan kosakata, dalam hal ini yang digunakan dalam teknik pancingan penelitian adalah beberapa daftar pertanyaan (2) teknik cakap semuka, bagian teknik cakap semuka ini penelitian langsung dilakukan dengan percakapan terhadap pengguna bahasa sebagai penutur dengan teknik pancingan yang telah disiapkan, dan (3) teknik rekam dan catat digunakan agar data yang diperoleh dapat direkam sebagai bahan acuan transkripsi data sedangkan teknik catat digunakan untuk mencatat sumber data tambahan. Jadi apabila ada yang kurang dimengerti pada data rekaman hal ini dapat dilihat kembali pada data catatan yang dicatat.Selain itu, peneliti menggunakan alat pengumpul data pada penelitian lapangan ini, hal ini digunakan untuk mempermudah dalam melakukan pengumpulan data sehingga hasil wawancara dapat terekam dengan baik dan penelitian ini memiliki bukti untuk sumber data. Alat bantu yang digunakan dalam pengumpulan data ialah kamera, perekam suara, dan buku catatan. Teknik analisis data yang digunakan dalam penelitian ini 
adalah mengkaji fungsi semantik kosakata alat dan teknik tangkap ikan bahasa Melayu Manado,khususnya yang digunakan oleh para nelayan.

\section{HASIL PENELITIAN DAN PEMBAHASAN}

Pembahasan keseluruhan data yang diperoleh dari penelitian ini dianalisis berdasarkan fungsi semantik leksikal dari kosakata alat dan teknik tangkap ikan menurut masyarakat nelayan di kawasan Bolevard Manado. Fungsi leksikal yang dimaksud adalah fungsi dari alat dan teknik yang dimanfaatkan menjadi bahan mata pencaharian oleh masyarakat nelayan yang masih menggunakan cara-cara tradisional dalam mencari ikan sekaligus alat-alat yang digunakan dalam kegiatan penangkapan ikan sebagian besar dibuat sendiri secara manual. Bahan-bahannya dapat diperoleh langsung dari alam; seperti rotan, kayu dan bambu.Bahan lainnya seperti tali, kail, dan benang dapat diperoleh di toko nelayan terdekat.

Hasil analisis fungsi semantik kosakata alat dan teknik penangkapan ikan pada masyarakat nelayan di kawasan Boulevar Manado adalah sebagai berikut:

Beberapa alat penangkapanikan pada masyarakat nelayan di pantai Boulevard wilayah Manado diuraikan di bawah ini.

\begin{tabular}{|c|c|c|}
\hline Kosakata & Fonetik & Fungsi semantic leksikal \\
\hline 1. Soma & [soma] & $\begin{array}{l}\text { Berfungsi sebagai alat } \\
\text { tangkap ikan yang terbuat } \\
\text { dari senar }\end{array}$ \\
\hline 2. Gumala & [gumala] & $\begin{array}{l}\text { Berfungsi sebagi mata } \\
\text { pancing untuk kail }\end{array}$ \\
\hline 3. Nunae & [nunaE] & Berfungsi sebagai umpan \\
\hline 4. Ladung & [laduy] & $\begin{array}{lrr}\text { Besi } & \text { pemberat } & \text { yang } \\
\text { berfungsi } & \text { sebagai } & \text { mata } \\
\text { pancing } & & \end{array}$ \\
\hline
\end{tabular}




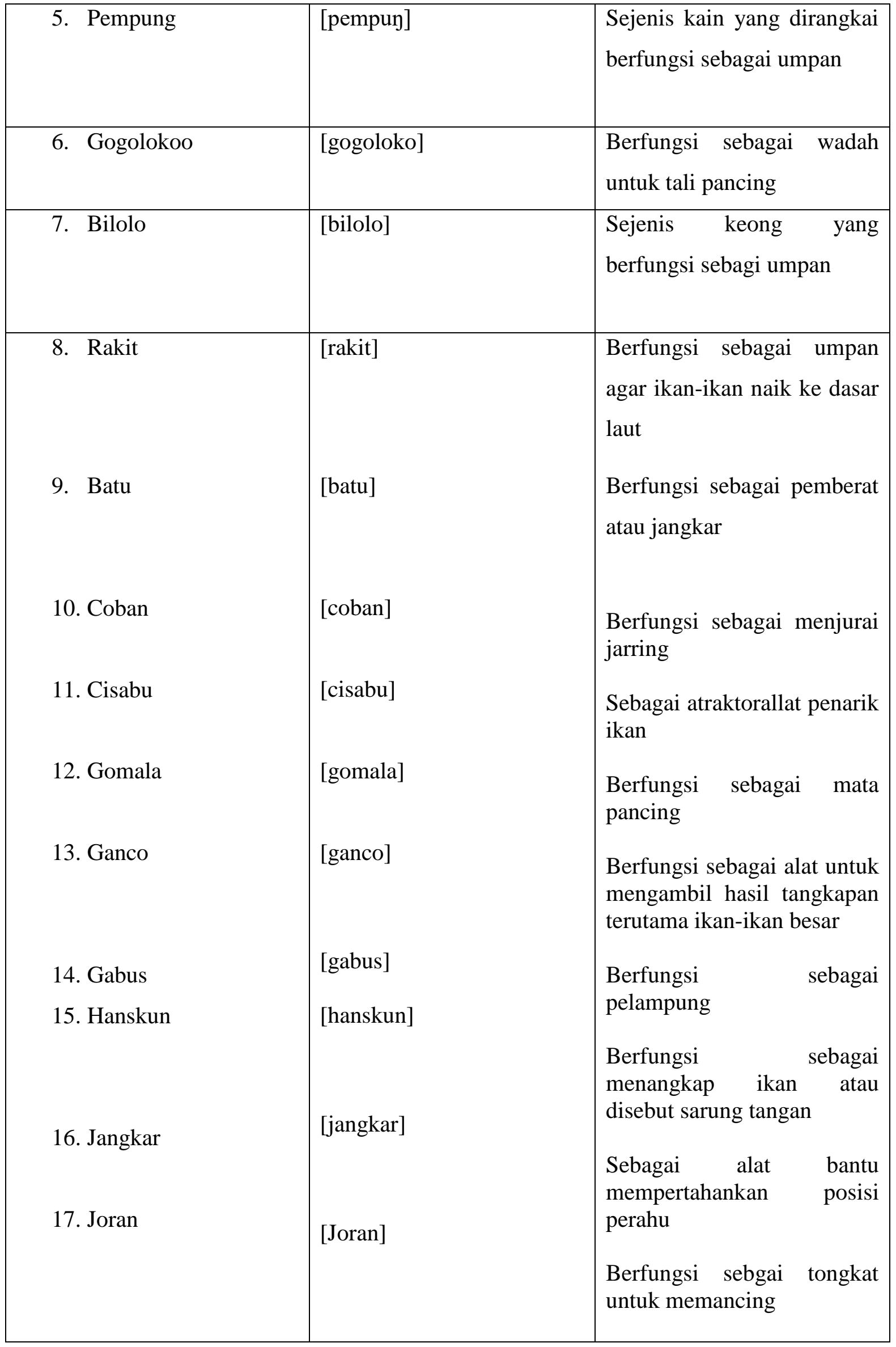




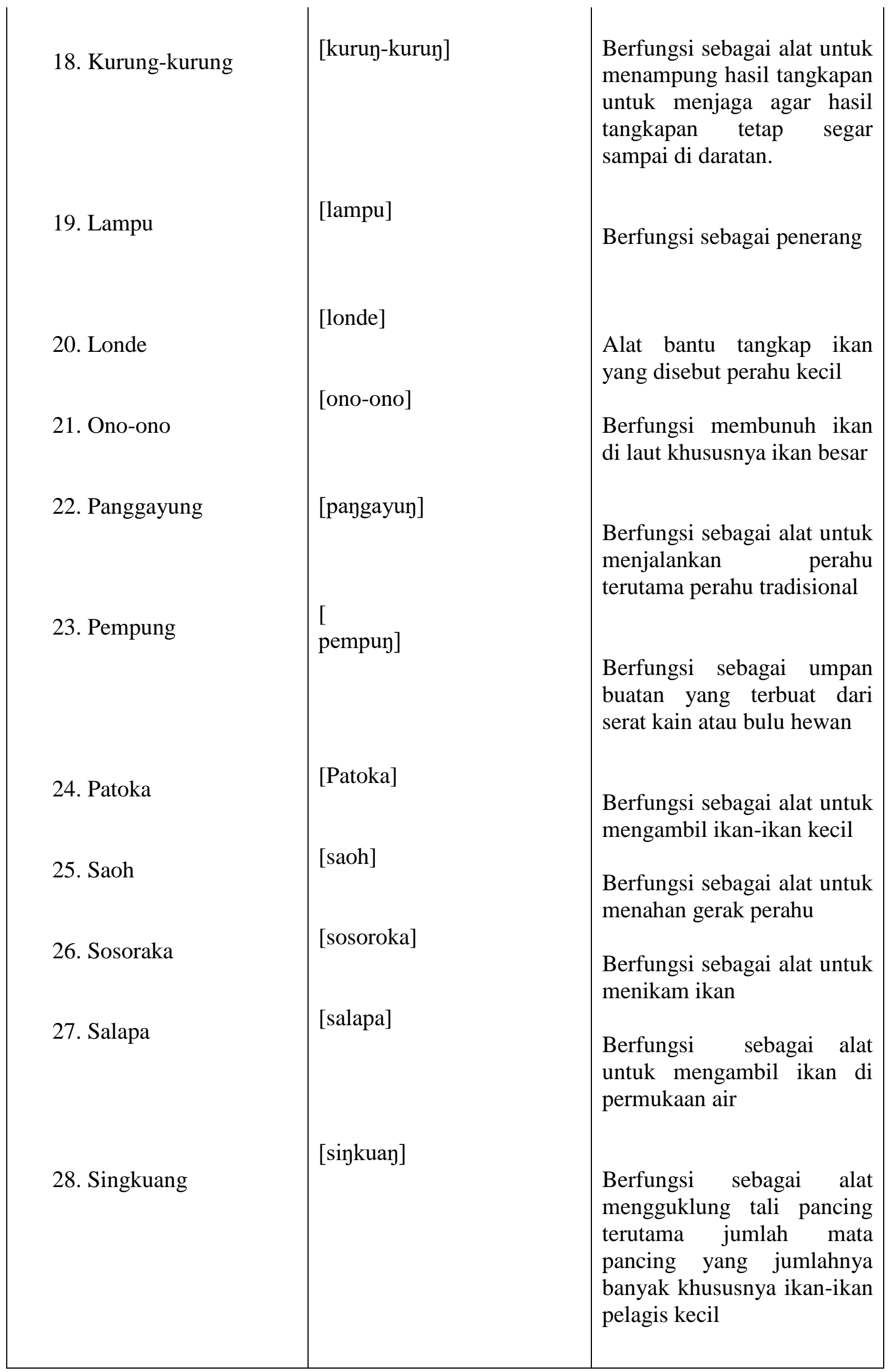




\begin{tabular}{|l|l|l|} 
29. Tenti & [tEnti $]$ & $\begin{array}{l}\text { Berfungsi sebagai pelindung } \\
\text { dari sinar matahari }\end{array}$ \\
30. Tolu & tolu $]$ & $\begin{array}{l}\text { Berfungsi sebagai pelindung } \\
\text { kepala }\end{array}$ \\
\hline
\end{tabular}

Beberapa teknik penangkapanikan pada masyarakat nelayan di wilayah Boulevard Manado diuraikan di bawah ini.

\begin{tabular}{|c|c|c|}
\hline Kosakata & Fonetik & Fungsi semantic leksikal \\
\hline 1. Nyare & [DarE] & $\begin{array}{l}\text { Berfungsi sebagai teknik } \\
\text { penangkapan ikan pada } \\
\text { waktu air surut. }\end{array}$ \\
\hline 2. Soma rarape & [soma rarapE] & $\begin{array}{l}\text { Berfungsi sebagai teknik } \\
\text { penangkapan ikan ysng } \\
\text { menggunakan jala dengan } \\
\text { skala yang lebih panjang, } \\
\text { dan dilepas pada saat air } \\
\text { pasang, setelah itu } \\
\text { menunggu sampai air surut. }\end{array}$ \\
\hline 3. Soma paka & [soma paka] & $\begin{array}{l}\text { Berfungsi sebagi teknik } \\
\text { penangkapan ikan yang } \\
\text { menggunakan jala, dengan } \\
\text { cara menenggelamkan } \\
\text { sampai ke dasar, kemudian } \\
\text { ikan-ikan diusir ke arah } \\
\text { jalah }\end{array}$ \\
\hline 4. Soma lalandra & [soma lalandra] & Berfungsi sebagai teknik \\
\hline
\end{tabular}




\begin{tabular}{|c|c|c|}
\hline & & $\begin{array}{l}\text { penangkapan ikan dengan } \\
\text { menggunakan jala, tapi tidak } \\
\text { menyentuh ke dasar }\end{array}$ \\
\hline 5. Manengkel & [manEykEl] & $\begin{array}{l}\text { Berfungsi sebagai teknik } \\
\text { penangkapan ikan yang } \\
\text { dilakukan pada saat malam } \\
\text { hari }\end{array}$ \\
\hline 6. Bajubi & [bajubi] & $\begin{array}{l}\text { Berfungsi sebagai teknik } \\
\text { penangkapan ikan yang } \\
\text { digunakan dengan cara } \\
\text { Memanah }\end{array}$ \\
\hline 7. Mangael & [mayaEl] & $\begin{array}{l}\text { Berfungsi sebagai teknik } \\
\text { penangkapan ikan dengan } \\
\text { cara menggunakan alat } \\
\text { pancing }\end{array}$ \\
\hline 8. Tato & [tato?] & $\begin{array}{l}\text { Berfungsi sebagai teknik } \\
\text { penangkapan ikan pada saat } \\
\text { air suru yang menggunakan } \\
\text { tumbak }\end{array}$ \\
\hline 9. Noru & [noru] & $\begin{array}{l}\text { Sebagai alat tangkap ikan } \\
\text { pelagis kecil }\end{array}$ \\
\hline 10. Sihoru & [sihoru] & $\begin{array}{l}\text { Sebagai teknik tangkap ikan } \\
\text { pelagis besar }\end{array}$ \\
\hline 11. Tono & [tono] & $\begin{array}{l}\text { Berfungsi sebagai teknik } \\
\text { tangkap ikan dasar }\end{array}$ \\
\hline 12. Palanto & [palanto] & $\begin{array}{l}\text { Mengail ikan besar maupun } \\
\text { ikan dasar peraira dengan } \\
\text { menggunakan banyak mata } \\
\text { pancing }\end{array}$ \\
\hline 13. Eke & {$[\mathrm{EkE}]$} & $\begin{array}{l}\text { Berfungsi sebagai teknik } \\
\text { tangkap ikan di pesisir } \\
\text { dengan menggunakan kail }\end{array}$ \\
\hline
\end{tabular}




\begin{tabular}{|l|l|l|}
\hline 14. Balandra & [balandra $]$ & $\begin{array}{l}\text { Berfungsi sebagai teknik } \\
\text { tangkap ikan dengan } \\
\text { menggunakan jarring }\end{array}$ \\
\hline
\end{tabular}

\section{SIMPULAN DAN SARAN}

\section{Simpulan}

Berdasarkan hasil analisis data penelitian ditemukan pada alat dan teknik tangkap ikan di kawasan boulevard Manado yaitu terdapat 30 kosakata pada alat tangkap ikan, dan 14 kosakata pada teknik tangkap ikan berupa hasil tersebut yang terkumpul dalam penelitian ini. Selain itu, yang dapat diberikan dari analisis fungsi semantik yang dibatasi menjadi makna leksikal bahwa kosakata alat dan teknik penangkapan ikan khususnya pada pemanfaatan teknik penangkapandan alat-alat tangkap tersebut. Ada beberapa kosakata alat - alat penangkapanyang cukup bervariasi atau hampir sama penamaannya namun mengacu pada fungsi yang berbeda sehingga hal ini dapat memperkaya kosakata. Selain itu, ada juga beberapa teknik penangkapan ikan yang menggunakan alat tangkap yang sama namun fungsi yang berbeda dalam hal penangkapan jenis ikan. Kajian kosakata alat dang teknik penangkapan ikan khususnya di Kawasan Boulevard Manado ini juga dapat dilanjutkan penelitiannya di daerah yang lain, guna untuk memperkaya kosakata yang berhubungan dengan teknik dan alat penangkapan ikan, sehingga dapat menambah jumlah kosakata yang telah teliti sebelumnya.

\section{Saran}

Berdasarkan hasil penelitian yang dilakukan peneliti, saran yang diberikan peneliti adalah sebagai berikut: (1) kajian kosakata alat dan teknik tangkap ikan hususnya pemanfaatan bagi masyarakat nelayan, merupakan kajian yang dapat memperkaya pengetahuan masyarakat Melayu Manado, peneliti mengharapkan penelitian selanjutnya dapat meneruskan kajian peneliti agar dapat memperkaya kosakata ini, (2) penelitian dapat dimanfaatkan untuk bahan referensi penelitian selanjutnya khususnya dalam penelitian kajian-kajian linguistik sehubungan dengan kosakata alat dan teknik tangkap nelayan. 
Selain itu, kosakata pada alat dan teknik tangkap ikan para nelayan ini diharapkan dapat dikembangkan menjadi kamus kosakata agar tetap terpelihara dan terjaga.

\section{Daftar Pustaka}

Aminuddin.2003. Semantik Pengantar Studi tentang Makna. Malang: Sinar Baru Agesindo.

Anton M. Moeliono. 1989. "Diksi dan Pilihan Kata" dalam Kembara Bahasa Kumpulan Karangan Tersebar. Jakarta: Gramedia.

Chaer, Abdul. 2009. Pengantar Semantik Bahasa Indonesia.Jakarta: Rineka Cipta.

Djajasudarma, T. Fatimah. 1999. Semantik 1 (Pengantar ke Arah Ilmu Makna). Bandung: PT RefikaAditama.

Djajasudarma, T. Fatimah. 2009. Semantik 1, Makna Leksikal dan Gramatikal.Bandung: Refika Aditama.

Jupitasari Mellisa. 2014. Fungsi Semantik kosakata etnobotani Melayu Sukadana: Artikel. Universitas Tanjungpura.

Kridalaksana, Harimurti. 2009. Kamus Linguistik. Jakarta: PT Gramedia Pustaka Utama. Leech, Geoffrey. 2003. Semantik Terjemahan. Paina Partana. Yogyakarta: Pustaka Belajar Moleong, Lexy J. 1989. Metodologi Penelitian Kualitatif. Bandung: Remadja Karya CV. Pateda, Mansoer. 2010. Semantik Leksikal. Jakarta: Rineka Cipta.

Parera, J.D. 2004. Teori Semantik. Jakarta: Erlangga.

Samarin, William J. 1988. Ilmu Bahasa Lapangan. Yogyakarta: Kanisius.

Sudaryanto.1993. Metode dan Aneka Teknik Analisis Data. Yogyakarta: Duta Wacana University Press.

Satori, Djam'an dan Aan Komariah. 2011. Metodologi Penelitian Kualitatif. Bandung: Alfabeta .

Sutopo, H. B. 2002. Metodologi Penelitian Kualitatif: Dasar-Dasar Teori dan Terapannya dalam Penelitian. Surakarta: Sebelas Maret University Press.

Suwandi, Sarwiji. 2008. Semantik Pengantar Kajian Makna. Surakarta: Media Perkasa.

Sugiyono. 2007. Memahami Penelitian Kualitatif. Bandung: Alfabeta.

Tarigan, Henry Guntur. 1995. Pengajaran Semantik. Bandung: Angkasa

Verhaar, J. W. M. 2001. Asas-asas Linguistik Umum. Yogyakarta: Gadjah MadaUniversity Press.

Wijana, I Dewa putu dan Muhammad Rohmadi.2008. Semantik Teori dan Analisis.Surakarta: Yusma Pustaka. 

Penangkapan Ikan Masyarakat Nelayan di Kawasan Boulevard Manado 